\title{
Identity Development of Female Adolescents Belonging to Illegal Armed Groups in Colombia.
}

\author{
Aguirre-Dávila, E.
}

Cita:

Aguirre-Dávila, E. (2020). Identity Development of Female Adolescents Belonging to Illegal Armed Groups in Colombia. Universitas

Psychologica, 19, 1-13.

Dirección estable: https://www.aacademica.org/eduardo.aguirre/18 ARK: https://n2t.net/ark:/13683/pkHo/atQ

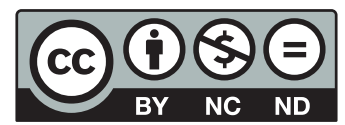




\title{
Identity Development of Female Adolescents Belonging to Illegal Armed Groups in Colombia*
}

\section{Desarrollo de la identidad de mujeres adolescentes pertenecientes a grupos armados ilegales en Colombia}

Received: 03 May 2017 | Accepted: 27 February 2020

\author{
Eduardo Aguirre-DÁvila \\ Universidad Nacional de Colombia, Colombia \\ ORCID: https://orcid.org/0000-0003-3292-5414
}

a Correspondence author. Email: eaguirred@unal.edu.co

How to cite this article: Aguirre-Dávila, E. (2020). Identity development of female adolescents belonging to illegal armed groups in Colombia. Universitas Psychologica, 19, 1-13. https://doi.org/10.11144/Javeri ana.upsy19.idfa

\begin{abstract}
The article presents the results of the research on the identity of the female adolescent soldiers who, at the time of the study, were in the Colombian government's rehabilitation programs. The life history interviews methodology was used, 20 adolescents and young women participated, with an average age of 18.9 years. When they entered the illegal armed groups, they had an average of 12.5 years and remained in the groups an average of 4.4 years. From the narratives of the participants, it was discovered that the development of their identity went through three key moments: the first is the product of family interactions, and it is expressed in the tension of assuming the traditional role of women and the decision to join to illegal groups; the second is the result of their permanence in the groups and is defined by the strong masculine culture of war; and the third moment is a consequence of the transit of these women through of the governmental rehabilitation programs, and it is characterized by assuming control of their lives from the exercise of citizenship.
\end{abstract}

Keywords

Adolescent soldiers; female identity; gender; guerrillas; rehabilitation programs.

\section{RESUMEN}

El artículo presenta los resultados de la investigación sobre la identidad de las adolescentes soldados, que en el momento del estudio estaban en los programas de rehabilitación del gobierno colombiano. Se utilizó la metodología de historias de vida, participaron 20 adolescentes y mujeres jóvenes, con una edad promedio de 18.9 años. Cuando ingresaron a los grupos armados ilegales, tenían un promedio de 12.5 años y permanecieron en los grupos un promedio de 4.4 años. A partir de las narrativas de las participantes, se evidenció que el desarrollo de su identidad pasó por tres momentos clave: el primero es el producto de las interacciones familiares y se expresa en la tensión de asumir el papel tradicional de las mujeres y la decisión de unirse a los grupos ilegales; el segundo es el resultado de su permanencia en los grupos y se define por la fuerte cultura masculina de la guerra; y el tercer momento es la consecuencia del tránsito de estas mujeres a través de los programas gubernamentales de rehabilitación, y se caracteriza por asumir el control de sus vidas a partir del ejercicio de la ciudadanía. 
Palabras clave

Adolescentes conbatientes; identidad femenina; género; guerrilla; programas de rehabilitación.

In the evolution of political violence in Colombia from the forties of the twentieth century three significant periods are identified, the first called "The Violence"" in the 1950s, the second "the National Front" and the third, "the internal armed conflict" (Cartagena, 2016). Children are linked to political violence, mainly in the period spanning from the seventies to the present. There is a significant presence of child and adolescent-soldiers involved in the Colombian internal armed conflict at this stage, with the main protagonists being armed groups ${ }^{1}$ like the Revolutionary Armed Forces of Colombia (FARC), the National Liberation Army (ELN), the M19 and the paramilitaries. All these groups recruit children for different tasks, including combat with the Colombian Army or opposition groups.

In terms of recruitment, different studies (Angucia, Zeelen, \& Jong, 2010; Castillo-Tietze, 2010; Gutierrez \& Carranza, 2017; Jiménez, 2009; Lugo, 2018; MacMullin \& Loughry, 2004; Molina, 2011; Moreno, Carmona \& Tobón, 2010; Orth, 2018, Thomas \& Wood, 2018) provide examples of girls and female adolescents enlisting in the armed groups for various reasons. In the case of Colombia, studies show that female adolescents' motivation to enlist in an armed group is not always violent nor against their will. There are cases in which forced conscription occurs. However, there are also many cases in which the girls and young women are motivated by conditions of domestic violence and poverty, by the presence the armed group has had in their community, by relationships with men in these groups, or sometimes they are inspired to join because they have family who serves in armed groups.

Despite their motives, there are bibliographical references, such as Bodineau (2014), Bouvier, (2016), Buchanan et al. (2013), Coalico (2007), Montoya (2014), Puentes (2012), Robjant et al. (2019), Smet (2009) and
Wessells (2016), who indicate that it is clear that serving in an armed group affects the way enlisted female adolescent socialize and construct their identities.

This paper examines the configuration of the identity of adolescent soldiers, which occurs in three vital moments in their development, in family life, during their time with the armed groups, and while in the governmental rehabilitation program, this "is a process in which children transition into civil society and enter meaningful roles and identities as civilians accepted by their families and communities" (Brooks, 2012, p. 293).

Before examining the identity of female adolescent soldiers, a definition of identity is needed.

The development of identity is related to both the physical maturation as well as social interaction. Over time the latter has more influence in shaping identity. In this regard, Larrain (2003) states that this is a defining process of self within the framework of the symbolic interaction with others. "The identity (...) is the ability to see oneself as object and in the process start building a narrative about one's self. But this ability is only acquired in a process of social relationships mediated by symbols" (Larrain, 2003, p. 32).

However, the development of identity is not a passive fact, a simple copy of the social environment, it is rather a bidirectional process in which the individual can select the elements that are most significant and seek to be recognized by others. The association between personal self and social support is bidirectional and mutually causative. The personal self "correspond widening circles of group membership. Different social contexts may trigger an individual to think feel and act on basis of his personal, family or national 'level of self'" (Hogg, 2001, p. 186).

Similarly, in the adolescent identity construction, the dynamical systems theory conceive this bidirectional and mutuality causative as a continuous dynamic interaction between person and environment, specifically, the interactions among endogenous factors (such 
as temperament, skills, capacities, thoughts, and feelings) and exogenous factors (such as relationships, experiences, socio-cultural norms, family history, etc.) (Diamond, Pardo, \& Butterworth, 2011; Kaplan \& Garner, 2017; Vignoles, 2011).

In this sense, the construction of the identity of adolescents occurs within the framework of dialectical relationships, which support, guide and ensure four key areas for their development: (a) the sense of competence, which translates into being able to do something right ; (b) the sense of utility because they have something to contribute; (c) the sense of belonging, that is, being part of a community and contributing to its progress; and (d) the sense of power by having control over their future (Field, Crothers, \& Kolbert, 2007)

In other words, identity is the product of a set of meanings that people make their own. These meanings have a social component that relates to social roles and social categorization. As the individual acts in multiple social roles are identified with multiple social categories, so the self-concept includes multiple social identities (Karelaia \& Guillén, 2014; Sedikides et al., 2011; Sedikides et al., 2013).

In this sense, another feature of identity is its hierarchical nature, that is, being the product of symbolic exchange and the individual meaning attributed to it, with multiple identities being formed, some of which are more salient or dominant than others. Regarding this aspect, Turner (2013), supported by the work of Stryker, says that:

Stryker reasoned that identities are parts of larger sense of self, and as such, they are internalized self-designations associated with positions that individuals occupy within various social contexts. Identity is thus a critical link between the individual and social structure because identities are designations that people make about themselves in relation to their location in social structures and the roles that they play by virtue of this location. Identities are organized into a salience hierarchy, and those identities high in the hierarchy are more likely to be evoked than those lower in this hierarchy.
Not all situations will invoke multiple identities, but many do. (p. 333)

When identity is activated in a particular situation by the role that must be played the individual operates a feedback loop as shown in the following figure.

\section{Figure 1.}

Identity Model

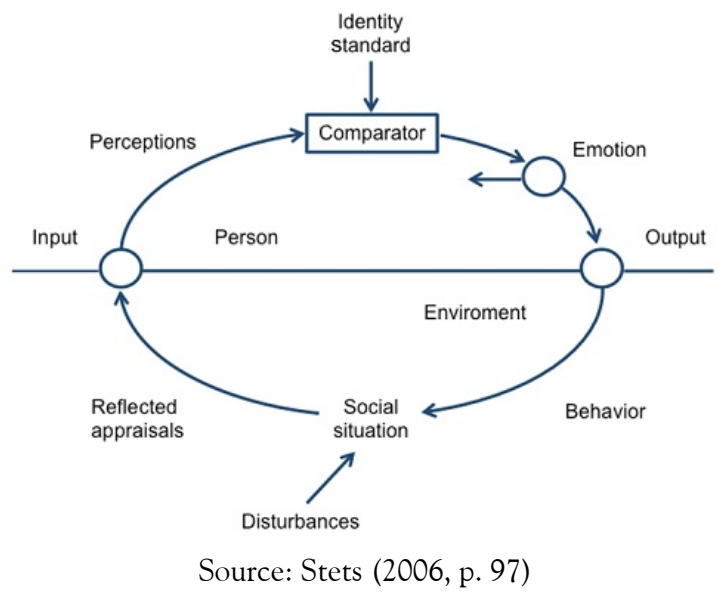

In this feedback loop, the particular role has an identity standard, often set through social norms and acquired through social interaction, which becomes a reference or comparator for the individual to evaluate whether her or his actions align with the standard. The actions are the output and behavior in the diagram. The environment is the full social situation and space for social interaction. Once the person has acted, she or he evaluates the behavior through the reflected appraisals. This leads to internal cognitive responses in the perception phase. These perceptions, in turn, affect the identity standards. Stets (2006) further explains this by noting:

The system works by modifying outputs (behavior) to the social situation in attempts to change the input to match the internal standard. In this sense, the identity system can be thought of as having a goal, that is, matching the situational inputs (perceptions) to the internal standards. What this system attempts to control is the perceptual input (to match the standard). When perceptions are 
congruent with the standard, identity verification exists. (pp. 96-97)

In identity control theory, multiple identities are controlled by separate systems, but the identity that has a more fundamental hierarchical value provides a more general framework for the lower levels of identities, which simplifies the control process (Turner, 2013). As stated before, identity can be seen as the self-perceived position the individual occupies in different situations and moments of one's social life.

This identity formation process plays an essential role in the development and definition of gender identity. Belonging to a gender (woman, men or a combination) determines the identity and substance of a person (Shah, 2018).

Gender refers to a set of characteristics that distinguish individuals and includes personality traits, social roles, habits and behaviors, which vary across time and cultures. Gender is a product of socialization and built from early childhood due to the cultural environment in which the individual is immersed. A primary scenario is family life in which are incorporated ways of thinking, acting and valuing of the feminine and masculine, conditioning that is the product of socio-cultural niche that shelters people. Carter (2014) states that the "family is usually the first unit with which children have continuous contact and the first context in which socialization patterns develop" (p. 244). It is important to note that the traditional Colombian family, especially rural Colombian families, are based on the dominant male social perspective.

Given that gender identity refers to how individuals see themselves as men, women, or some combination of both, we can say, following a feminist perspective, that the situation of women is as a condition in which they "suffer systematic social injustice because of their sex" (Freedman, 2004, p. 15). This feminist model argues that the formation of the female identity is associated with cultural practices of submission, learning tasks and domestic responsibilities, and the opposition of male and female (GarcíaLeiva, 2005). This sexist view of interpersonal relationships manifests itself in different forms in contemporary societies.

Butler (2007) mentions how that for many women of the world, gender norms guide social practices, but not always towards scenarios of freedom. More often, the opposite is the case, which means that a change in gender norms is the true path for the transformation of reality for women.

It is in the context of high vulnerability that the construction of the identity of female adolescents belonging to armed groups occurs. Family conditions of poverty, violence and submission to cultural values marked by machismo, are what determine the identity processes of these adolescents (Bouvier, 2016; Lugo, 2018). In this case, being a woman goes through the naturalization of the traditional roles assigned to women, such as assuming domestic tasks, being a wife and mother, without adolescents envisioning another type of identity that allows them to gain greater dominance of themselves (Thomas \& Wood, 2018).

Only the recognition of the conditions of disadvantage, submission and violence, allows adolescents to face more successfully the challenges of an exclusionary social environment since it allows them to make changes in their personal life and social environment, especially in cases of high vulnerability (Dunst, 2017).

\section{Method}

The life history interviews instrument (Legrand, 1992; Atkinson, 2002) was selected to understand the meaning of the experiences of 20 female adolescent soldiers detached from Colombian armed groups.

To understand the meaning and the emerging structure of life history interviews (Cornejo, Mendoza \& Rojas, 2008), first, there is a logical analysis of intra-case of life history to focus on the peculiarities of the stories and be able to reconstruct the biographical milestones in the narrator's life. Second, there is a logical transversal analysis of inter-cases to establish common themes in the life history. 


\section{Participants}

The participants (20) were selected from governmental rehabilitation programs that are responsible for receiving demobilized female adolescents to facilitate their reincorporation into civilian life. The participants were spread across 17 cities in Colombia, with an average age of 18.9 years old, 12.5 years when they entered the armed groups and remained in these groups an average of 4.4 years.

\section{Instruments}

Data collection used two instruments, a sociodemographic questionnaire and a guide to the life history, which were structured around significant life moments: a) in the past, b) present life, c) preparing for the future.

The categories used for the development of the instruments were: Individual Characteristics, Family Characteristics, Social Characteristics, Community Characteristics and Institutional Characteristics.

\section{Ethical Statement}

The research has been adjusted to international ethical standards, and informed consents were included for all participants in this study.

\section{Results}

The information collected in the life history interviews of female adolescents linked to armed groups, allowed to be located three moments in the reconstructed timeline based on their narrative: before joining the armed groups; during their stay in the armed groups and the transit by governmental rehabilitation programs in the Family Context

The conditions of the teenagers' homes before joining the armed groups, outlined from their voices, shows a traditional Colombian family environment in which occurs the first configuration of their identity. In the stories, the teenage girls perceived the representation of women as victims of invisibility, discrimination and inequality. Even in the second decade of the 21 st century, women suffer and live like sexist and violent cultural baggage, with the aggravating circumstance that of such discrimination existing for minor girls.

The representation of women, of the feminine, is given as a continuation of the predominant discourse of gender, where adolescents reproduce the traditional codes of the role of women in the home, including submission and abuse against women and about love and relationships, in the sense like Larrain (2003) states, that is, that the identity-building results of individual's narrative when she/he take one

"For me the situation was (...) [I was] angry with him [stepfather], because he said that he was the rooster, then he was singing, he was the one who gave orders [in the house], and he said that the other did what he said and now."

"'My family was very conflictive. My mom and dad fought a lot, my dad came drunk and he beat my mom. The life was a very complicated because my parents kept fighting." (Narratives of the participants)

The demobilized female adolescents experienced extreme living conditions, and because they are women were subjected to prejudices, which perpetuate genderdiscriminatory traditions that shape their identity.

However, as proposed the dynamical systems theory, even in these difficult conditions of life is possible to identify a characteristic related with authentic empowerment, in the decisions to leave home and join an armed group. Adolescents make this decision pushed by domestic violence, difficult economic conditions, emotional relationships or image of power that members of armed groups possess.

"The truth I did not dream much because there [rural area] one does not have as much future..."

"Life in my house was terrible. Once I said I don't want to live with my mom, where do I go? Who do I live with? And there came a time, at about the 11 years, that I said I'm leaving home, 
I am going because of the way my mom treats me..." (Narratives of the participants)

The development of the identity of the participants, which is deducted from their narrations, shows that it is a stage of life that is determined by the tension between continuing the realization of the traditional role of women under violent conditions, and the relatively conscious decision to join to insurgent and illegal activities, which reflects a broader desire for freedom and empowerment for women. This role, framed in the undervaluation of, and discrimination and violence against women, is played out mainly in the everyday activities around the household, maternity, family care, and a life full of risks.

According to the narrations, it can be inferred that identity in the early teens has been structured within a frame of violence and the need to find solutions to the condition of exclusion. The decision to join guerrillas and paramilitaries, which occurs with limited information and knowledge of the world of these groups, ends with them choosing the lifestyle of female adolescent soldiers. This decision, which occurs in a context of uncertainty, violence and war, shows that the circumstances give them a degree of independence to choose, in terms of cost-benefit, for the lesser evil in their life course. However, this crucial life decision can have consequences the same as or worse than if they had stayed at home.

The situation of the female adolescents before joining to the armed groups was adverse to their development, especially from the family context, which was a scenario that projected a traditional model of feminity, oppression and subordination. These oppressed family environments show them what would be their experience of oppression as adult women in a patriarchal Colombian social system.

\section{In the Armed Groups}

The conditions of poverty and vulnerability added to the pressure of the adverse circumstances that are experienced in families leads female adolescents to decide on joining the guerrillas, marked by uncertainty, risk and intuition of not be a favorable option. In other cases, by the proximity of the armed conflict, they are forced by these groups to join them. In both cases, the warzone they enter constitutes a new moment in the construction of their identities.

The armed groups were not an unknown phenomenon for the teenagers: on the contrary, it was a circumstance that was often present throughout their daily lives. Members of the armed groups frequent the premises or farms where they live, or some relatives and acquaintances belong to these organizations.

"I recognized a boy who lived in my town, that boy was part of that group. He was a guerrilla member. Then I became very friendly with him and he started talking to me" (Narratives of the participants)

Upon reaching the group, building femininity goes into the background for the gender identity of the teenage girls, especially in the initial stages because it passes from a conception of women given from their experience in the family to one focused on the materiality of the body useful for war. In the words of Foucault (1995): "expelling the peasant and giving air to the soldier." The identity of the female adolescent soldier is reconstructed around an identity standard based on strongly male or masculine references and standards.

The identity of girl soldiers transforms with their entry into the armed groups. In this scenario the identity is determined by the social categorization associated to the war, it which build a new form of being over the scaffolding of the previous identity, making accessible the self of adolescents in the intra-group context and identifiable in the out-group context. In other words, now the adolescent soldiers' identity would consist of the aspects of self-image coming of the new social category to which they belong (radio operator, nurse, cook, soldier, etc.), which is summarized in the integrative category of a guerrilla or paramilitary fighter.

Thus, recruitment constitutes an abrupt upheaval in the lives of female adolescent 
soldiers, producing a series of changes in roles and gender identity. Under these circumstances is evidenced in female adolescence the capacity of adaptation to the requirements of war. The first requirement of this new context for female recruits is to adapt to the conditions of "equality" in the execution of the tasks specific to these groups, assuming responsibilities from the beginning regardless of gender. This leads the girls to assume the roles and characteristics attributed historically to men.

This homogenization produced by these contexts of war gives teens the fictional sense of equality in relationships and the treatment, which is something that empowers them considering their family history of discrimination and inequality. This perception of equality, though mistaken, begins operating within them as part of their identity standard, and influences the construction of identity that is based on a distinctly male referent.

"I and others were on patrol, had the same work as men, like a day of guard duty."

"There, one felt like a man because one does activities that men do normally - the weight load is the same, and the exercises are the same."

"They gave us a special forces course, and I left because of a foot wound (...) I was afraid, and I was sad to know that I was there harming humans beings like me. It made me sad." (Narratives of the participants)

Another aspect that contributes to the construction of identity marked by equality is the need to protect one's life. In this scenario the female adolescent soldier, acting under the logic of war, are more aware that life is played daily at the armed group, fulfilling different functions that supporting the war device, either serving on equal terms that men like "radista" (radio operator), nurse, fighter or, in some cases, coordinator of the group.

"Well, the military confrontation taught me that one must be strong and not give up for anything (...). They tell us that one has to be brave, be strong, but I was gaining strength by myself because there one has to defend oneself, one has to fend for oneself and defend oneself with the gun, like men." (Narratives of the participants)

In the life of the armed group, this idea of equality is reinforced by the demands that everyone is made to perform household and farm, such as cooking, cleaning, look for firewood or planting tasks. In the perception of adolescent women in these tasks, the role of gender was not distinguishable, thus are transformed artificially the different functions assigned to women and men by a patriarchal society, outside of armed groups.

"(..) everything was the same, it was fair, what women do what men did also, sow plants, banana, cassava, clean, look for firewood, cooking, everything that men do on the farm."

"They think we should all be equal, there is no difference between a man and a woman, all must be equal, then, as the guerrillas give women the opportunity to also fight for what they want." (Narratives of the participants)

Thus, the context of the armed groups is what determines a new state of adolescent identity, which expresses the values and behaviors of war, mainly assumed from a male perspective.

\section{In the Governmental Rehabilitation Programs}

The entry of female adolescent combatants into the institutional rehabilitation system, as part of the transition to civilian life, traces a path towards roles and contexts that are much more empowered, but that always seemed elusive for them. It is a paradox that they had to undergo such extreme experiences of passing through an armed group to get the opportunity to access reasonable education, health and work experiences, and be understood as equal citizens to men.

"Even though I had an experience that I would not wish on anyone, now I'm studying. I have seen beautiful things that I dreamed to see, that is, life changed completely despite the experience, but sometimes one has to pass through it. If God allowed me to be here, it must 
be for something. He allowed this to happen to me, so that my life is different." (Narratives of the participants)

This new scenario for the restoration of rights makes evident that female adolescent soldiers have become more aware of a fuller notion of what it means to be a woman, a broader model of femininity than what they had in their past family or wartime experiences, and which allows them to be seen as a social subject.

"I myself feel good about being a woman (...) I am proud of being a woman"

"I think one does not have to show off or be thinner, prettier, presented. No, the most beautiful and the most valuable thing for a woman is what is inside."

"We need to take over the role of women, who are now more prepared, more capable of facing everything." (Narratives of the participants)

Furthermore, it is evident that experiences of the teenagers, both in the family as in the armed groups, contributed to this empowerment, which is reinforced by the institutional rehabilitation work. The transition through the rehabilitation institutions fed them discourses and notions of equality, more appropriate for the new lifestyle they will have.

The stories of female adolescent soldiers related to their institutional experience expressed a rejection of the aggression of couple and submission to male desires, a clear conception of not being less than a man. The armed conflict showed them that they have the same capabilities as men and gave them the determination to build a new life and a consciousness of being subjects of law.

"I think we have many values and that here and elsewhere we can succeed and also show that as women we have to make others respect us and not allow ourselves to be influenced."

"I think the [rehabilitation] process is great. I came here with a broken heart, with low selfesteem, but thanks to the housemates and my program psychologist, I'm a different person and I want to follow forward." (Narratives of the participants)
Certainly, the training they receive in the State rehabilitation institutions, who are responsible for their incorporation into civilian life, allows them to experience the rights that they are entitled to and to set out in their new narrative, appropriating the rights that are common to humanity.

\section{Discussion}

In the collection of information, all participants identified their gender under their biological sex. The analysis of the results allowed to show that the development of identity occurs, as Larrian (2003) affirms, in the framework of symbolic interaction with others. Thus, the contexts in which the life of female adolescents linked to armed groups takes place, full of symbolic mediations, shape the perception of oneself and relationships with others.

In the participants' narratives, the family environment appears as a first scenario in which identity is constructed as a woman, since they show that their family relationships were marked by the traditional role assigned to women. As Freedman (2004) and García-Leiva (2005) pointed, in this context, female identity is generally associated with cultural practices of submission, domestic tasks and responsibilities and the opposition of men and women.

Following Butler (2007), it can be affirmed that female adolescents embody a sexist vision that does not guide social practices towards scenarios of freedom. As Cajamarca (2012) points out, the experience of being a woman for a high percentage of girls continues to be crossed by discrimination that accentuates the conditions of poverty and inequality, and by a historical framework that has given rise to relationships and roles characterized by submission as manifest or incontrovertible destiny.

It is in this context that female adolescents make the decision to join the armed groups and this opens a path of transformation of the gender norms present in the traditional family context, which would give them, in the words of Butler (2007), the possibility of experiencing 
something that may have a seal of freedom and the configuration of a new scenario for the development of identity. However, it should be noted that this decision is framed in a stage of ontogenetic development that does not give the possibility of considering it completely conscious, given that it is forced by family and socioeconomic conditions, and by armed conflict.

Under the pressure of precariousness, female adolescents are driven to join armed groups with diverse motivations, ranging from the idealization of guerrilla or paramilitary life to a search for better living conditions (Lugo, 2018; Moreno et al., 2010; Niño, 2016). Then, it can be affirmed, following Dunst's statement (2017), that only the recognition of the conditions of disadvantage, submission and violence, allows these women to face the challenges of an exclusive social environment. In the narratives of female adolescents, there is a change of perception of their situation within the armed groups, which goes from a sense of limitation and insecurity in family life to another of equality and empowerment in the group.

However, this perception of equality and empowerment is a mere illusion because, in the context of war, which sustains a masculine perspective of domination, strength, subordination and violence, women are once again invisible. In this context, as Turner (2013) states, the identity is the designation that people make of themselves regarding their location in social structures and the roles they play under this location, then, female adolescents' identity that appears in their narratives is built on the masculine paradigm of strength and domination, and femininity goes to the background, given that adolescent girls only in their spare time can assume their femininity, for example, focusing on their personal arrangement, although in the guerrilla's daily life assumes war actions in conditions of male equality with respect to the responsibilities and tasks assigned by the armed groups.

In the female adolescents' life history there is a new state of the construction of their identity, which occurs within the framework of attention in governmental rehabilitation programs, that seeks to build social inclusion and restore the dignity and integrity of female adolescents. This facilitates their inclusion in the educational system, developing livelihood skills, and strengthening their participation in social environments, so that they are prepared to succeed in civil life.

In this scenario, the identity of female adolescents is expressed in a new way of empowerment, which differs from that exercised in armed groups marked by violence. This new facet of his identity is based on higher education, on the awareness of free participation in society, on positive self-assessment, on the reconstruction of her emotional ties with the family, and on feeling more secure in facing her future as a woman.

Finally, if we start from the idea of Tajfel (1978), Tajfel and Turner (1986) and Stryker and Burke (2000) that identity of an individual is not static but evolves progressively over time, and that those aspects of self-derived from social categories to which the individual perceives belong. It is clear that in the new stage like is the institutional life, the attitudes, norms and behaviors of the group of belonging become part of the identity of adolescent girls. Thus, in the institutional context, democratic values and behaviors defined in the transformation of the identity of the teenage girls.

\section{Conclusions}

The article presents the scenarios in which the identity of female adolescent linked to armed groups develops. The first refers to the traditional Colombian home, in which a representation of women is reproduced as victims of invisibility, discrimination, inequality, and practices marked by submission and abuse. The second scenario refers to life within the armed groups, in which the development of identity is marked by war and by the new roles historically attributed to men, such as being a combatant, radio operator, and informant, all of which gives a false idea of gender equality, because the identity that emerges is based mainly on a clearly masculine 
referent. Finally, there is a third scenario related to governmental rehabilitation programs as a means of transition to civilian life and rights restoration, in which adolescents reach a better awareness of what it means to be a woman. This notion is based on a broader model of femininity than they had in family experience or war and expresses a new identity that allows them to see themselves as social subjects.

The identity of female adolescents that is built in civil life goes through the recognition of personal strengths and self-healing attitude, as well as the enjoyment in the exercise of rights and the construction of citizenship. Their self-perception is guided by the recognition of being building a life plan and being motivated to carry it out. This self-perception, which appears in life stories, allows us to conclude that government rehabilitation programs have a positive impact on them because it allows them to overcome situations experienced in the family environment, in armed groups, and their permanence in legality.

Among the aspects that were not discussed in this work and that can be addressed in future research are: a closer approach to the process of incorporating female adolescent to civilian life, a greater deepening in the meaning of the maternal experience and the identification of the social representations of couple life.

\section{References}

Angucia, M, A., Zeelen, J., \& Jong, G. (2010). Researching the reintegration of formerly abducted children in northern Uganda through action research: Experiences and reflections. Journal of Community $\&$ Applied Social Psychology, 20(3), 217-231. https://do i.org/10.1002/casp.1034

Atkinson, R. (2002). The Life Story Interview. In J. F. Gubrium \& J. A. Holstein (Eds.), Handbook of interview research. Context $\mathbb{E}$ Method (pp. 121-140). Thousand Oaks: Sage Publications.

Bodineau, S. (2014). Vulnerability and agency: figures of child soldiers within the narratives of child protection practitioners in the democratic Republic of Congo. Autrepart, 4(72), 111-128. https://doi.org/1 $0.3917 /$ autr.072.0111

Bouvier, V. M. (2016). Gender and the role of women in Colombia's Peace Process. NY: UN Wome.

Brooks, J. (2012). The Struggle of Girl Soldiers Returning Home. A Journal of Social Justice, 24(3), 292-297. https://doi.org/10.1080/10 402659.2012.704255

Buchanan, M. J., Al-Mashat, K., Cortés, L., Djukic, B., Jaghori, B., \& Thompson, A. (2013). Children of war in Colombia and Iraq. In C. Fernando \& M. Ferrari (Eds.), Handbook of resilience in children of war (pp. 107-116). NY: Springer Science+Business Media. https://doi.org/10.1007/978-1-4614 $-6375-7$

Butler, J. (2007). El género en disputa. El feminismo y la subversión de la identidad. Barcelona: Paidos.

Cajamarca, M. R. (2012). Por ser niña: Situación de las niñas en Colombia 2012. Esa niña también soy yo. Bogotá, D. C: Fundación Plan Colombia.

Cartagena, C. (2016). Los estudios de la violencia en Colombia antes de la violentologi\#a. Diálogos Revista Electrónica de Historia, 17(1), 63-88. Recuperado de https://www.r edalyc.org/pdf/439/43942944004.pdf

Carter, M. J. (2014). Gender socialization and identity theory. Social Sciences, 3(2), 242-263. https://doi.org/10.3390/socsci302 0242

Castillo-Tietze, D. (2010). ¿De actores en armas a sujetos sociales? Niñas excombatientes, procesos de desarme, desmovilización y reinserción. Bogotá, D.C.: Terre des Hommes y FEDES.

Coalico. (2007). Informe sobre la situación de niños, niñas, y jóvenes vinculados al conflicto armado en Colombia. Coalición contra la vinculación de niños, niñas y jóvenes en el conflicto armado en Colombia and CEJIL.

Cornejo, M., Mendoza, F., \& Rojas, R. C. (2008). La Investigación con relatos de vida: Pistas y opciones del diseño metodológico. Psykhe, 
17(1), 29-39. https://doi.org/10.4067/S071 8-22282008000100004

Diamond, L. M., Pardo, S. T., \& Butterworth, M. R. (2011). Transgender experience and identity. In S. J. Schwartz, K. Luyckx \& V. L. Vignoles (Eds.), Handbook of identity theory and research(Vol. 2, pp. 629-647). NY: Springer. https://doi.org/10.1007/978-1 -4419-7988-9_26

Dunst, W. S. (2017). Feminist Identity Theory: Downing and Roush's Model of Positive Feminist Identity Development. NY: Stony Brook University. https://doi.org/10.13140/ RG.2.2.22569.24169

Field, J. E., Crothers, L. M., \& Kolbert, J. B. (2007). Adolescent Female Gender Identity and Attraction to Male Bullies and Victims. Journal of Emotional Abuse, 7(1), 1-15. https://doi.org/10.1300/J135v07n01_ 01

Foucault, M. (1995). Discipline and punish: The birth of the prison. NY: Random House, Inc.

Freedman, J. (2004). Feminismo iunidad o conflixto? Madrid: Narcea, Colección Mujeres.

García-Leiva, P. (2005). Identidad de género: Modelos explicativos. Escritos de psicología, 7, 71-81.

Gutierrez, F., \& Carranza, F. (2017). Organizing women for combat: The experience of the FARC in the Colombian war. Journal Agrarian Change, 17, 770-778. https://doi.o rg/10.1111/joac. 12238

Hogg, M. A. (2001). A social identity theory of leadership. Personality and Social Psychology Review, 5(3), 184-200. https://doi.org/10.12 07/S15327957PSPR0503_1

Jiménez, C. (2009). Between rationality and intuition: A social psychology approach to ex-combatant children in Colombia. IDS Bulletin, 40(3), 58-64. https://doi.org/10.11 $11 / \mathrm{j} .1759-5436.2009 .00039 . \mathrm{x}$

Kaplan, A., \& Garner, J. K. (2017). A complex dynamic systems perspective on identity and its development: The dynamic systems model of role identity. Developmental Psychology, 53(11), 2036-2051. https://doi.o $\mathrm{rg} / 10.1037 /$ dev0000339
Karelaia, N., \& Guillén, L. (2014). Me, a woman and a leader: Positive social identity and identity conflict. Organizational Behavior and Human Decision Processes 125(2) 204-219. https://doi.org/10 $.1016 / j . o b h d p .2014 .08 .002$

Larrain, J. (2003). El concepto de identidad. Comunicação $\mathfrak{E}$ Cultura, 21, 30-42. https:// doi.org/10.15448/1980-3729.2003.21.3211

Legrand, M. (1992). L'Approche biographique: Théorie, méthode, pratiques. Análise Psicológica, 4(X), 499-514.

Lugo, V. (2018). Niños y jóvenes excombatientes en Colombia: ipor qué se vinculan y separan de la guerra? Athenea Digital. Revista de Pensamiento e Investigación Social, 18(2), 1-22. https://doi.org/10.5565/rev/ath enea. 1933

MacMullin, C., \& Loughry, M. (2004). Investigating psychosocial adjustment of former child soldiers in Sierra Leone and Uganda. Journal of Refugee Studies, 17(4), 460-472. https://doi.org/10.1093/jrs/17.4.4 60

Molina, G. P. (2011). La atención estatal a menores de edad desvinculados del conflicto armado: el Hogar José. Bogotá, D.C.: Universidad Nacional de Colombia.

Montoya, V. P. (2014). Former girl soldiers in Colombia: Young voices that need to be heard [Master's thesis, Dalhousie University]. Semantic Scholar. https://pdfs.semanticscholar.org/4 bff/6185dc960be30f19641ff434e488864fb6 83.pdf

Moreno, F., Carmona, J. A., \& Tobón, H. (2010). ¿Por qué se vinculan las niñas a los grupos guerrilleros y paramilitares en Colombia? Revista Latinoamericana de Psicología, 42 (3), 453-467. http://www.scielo.org.co/pdf/rlps/ v42n3/v42n3a09.pdf

Niño, N. (2016). Niños, niñas, jóvenes y grupos armados ilegales: Experiencias de exclusión e inclusión social en América Latina. Publicación del Instituto de Investigaciones Gino Germani, 18, 177-206. https:// publicaciones.sociales.uba 
.ar/index.php/argumentos/article/downloa $\mathrm{d} / 2029 / 1724$

Orth, M. (2018). She Was Colombia's Most-Feared Female Revolutionary. Can She Help It Find Peace? Vanity Fair. https://www.vanityfair.com/news/201 8/08/colombia-civil-war-farc-female-revolu tionary

Puentes, J. M. (2012). La incidencia del programa de atención especializada a niños, niñas y adolescentes desvinculados de grupos armados irregulares del ICBF en el proceso de reintegración social en Colombia. [Unpublished master's thesis]. FLACSO.

Robjant, K., Koebach, A., Schmitt, S., Chibashimba, A., Carleial, S., \& Elbert, T. (2019). The treatment of posttraumatic stress symptoms and aggression in female $\mathrm{T}$ former child soldiers using Adapted Narrative Exposure Therapy - a RCT in Eastern Democratic Republic of Congo. Behaviour Research and Therapy 123, 103482. https://doi.org/10.1016/j.brat.2019 .103482

Sedikides, C., Gaertner, L., Luke, M. A., \& O’Mara, E. M. (2011). Individual self, relational self, collective self- hierarchical ordering of the tripartite self. Psychological Studies, 56(1), 98-107. https://doi.org/10.10 07/s12646-011-0059-0

Sedikides, C., Gaertner, L., Luke, M. A., O'Mara, E. M., \& Gebauer, J. E. (2013). A three-tier hierarchy of self-potency: individual self, relational self, collective self. Advances in Experimental Social Psychology, 48, 235-295. https://doi.org/10.1016/B9780-12-407188-9.00005-3

Shah, S. B. (2018). Woman question, identity and the emergence of feminism. IRAInternational Journal of Management $\mathbb{E}$ Social Sciences, 12(2), 17-24. http://dx.doi.org/10. 21013/jmss.v12.n2.p1

Smet, S. (2009). A window of opportunity: improving gender relations in post-conflict societies: The Sierra Leonean experience. Journal of Gender Studies, 18(2), 147-163. ht tps://doi.org/10.1080/09589230902812455
Stets, J. E. (2006). Identity theory. In P. Burke (Ed.), Contemporary social psychological theories (pp. 88-110). Stanford, CA: Stanford University Press.

Stryker, S., \& Burke, P. J. (2000). The past, present, and future of an identity theory. Social Psychology Quarterly, 63(4), 284-297. https://doi.org/10.2307/2695840

Tajfel, H. (1978). Differentiation between social groups: Studies in the social psychology of intergroups relations. London: Academic Press.

Tajfel, H., \& Turner, J. C. (1986). The social identity theory of intergroup behavior. In G. Austin \& S. W. Worchel (Eds.), Psychology of intergroup relations (pp. 7-24). Chicago: Nelson Hall Publisher,

Thomas, J. L., \& Wood, R. M. (2018). The social origins of female combatants. Conflict Management and Peace Science. 35(3), 215-232. http://dx.doi.org/10.1177/073889 4217695524

Turner, J. H. (2013). Contemporary sociological theory. Newbury Park, CA: SAGE Publications, Inc. https://doi.org/10.4324/9 780203505984-16

Vignoles, V. L. (2011). Identity Motives. In S. J. Schwartz, K Luyckx \& V. L. Vignoles (Eds.), Handbook of Identity Theory and Research (Vol. 1, pp. 403-432). NY: Springer. https:// doi.org/10.1007/978-1-4419-7988-9

Wessells, M. G. (2016). Reintegration of child soldiers: The role of social identity in the recruitment and reintegration of child soldiers. In S. McKeown, R. Haji \& N. Ferguson (Eds.), Understanding peace and conflict through social identity theory (pp. 105-120). Peace Psychology Book Series. Springer, Cham. https://doi.org/10.1007/97 8-3-319-29869-6_7

\section{Notes}

* Research article. The data were taken from the study of 2013 "An analysis of individual, familiar, social, community, and institutional characteristics associated with the demobilization and reintegration of girls 
and young women who have belonged to illegal armed groups", directed by the author of this article, which was funded by the International Organization for Migration (IOM) and Mercy Corps, and for their implementation with the support of the Colombian Family Welfare Institute (ICBF acronym in Spanish) and the Colombian Agency for Reintegration (ACR acronym in Spanish).

1 Usually, opposition armed groups are simply called "armed groups" or "armed opposition groups" in most conflicts. However, the Colombian government refers to such groups as "groups operating outside the law" to distinguish such groups from Colombian military forces. In this paper, armed groups refer to any Colombian armed group other than the Colombian military. 